\title{
Mid-Cretaceous acanthomorph fishes with the description of a new species from the Turonian of Lac des Bois, Northwest Territories, Canada
}

\author{
Alison M. Murray \\ Department of Biological Sciences, University of Alberta, Edmonton, AB, T6G 2E9, Canada, \\ ammurray@ualberta.ca
}

\begin{abstract}
A single specimen of a new acanthomorph fish is described from a Turonian locality sampling the northern part of the Cretaceous Western Interior Seaway. This brings to three the number of acanthomorphs from Lac des Bois, Northwest Territories, Canada. The previously named acanthomorph, Boreiohydrias dayi (Boreiohydriidae), was placed in the Polymixiiformes. The second, represented by a poorly preserved fish, was left unnamed and incertae sedis in Acanthomorpha. The new taxon described here, Cumbaaichthys oxyrhynchus gen. et sp. nov., cannot be easily placed in any previously described family. This fish is placed in the Polymixiiformes based on the caudal skeleton having 18 principal rays (16 branched), and having a full neural spine on the second preural centrum. Polymixiiform relationships are not well established but they are the subject of several current studies; therefore, the new acanthomorph is placed incertae sedis within this order but with the understanding that this placement may be refined with future work. Previous studies have suggested that acanthomorphs may have flourished with warming climates of the Cenomanian-Turonian. A comprehensive survey of named acanthomorphs from mid-Cretaceous deposits shows there are more species known from the Cenomanian than from the Turonian, although this may be biased by the age of known fossiliferous deposits.
\end{abstract}

http://zoobank.org/urn:Isid:zoobank.org:pub:25860DEC-350D-48BD-AD6A-9BoA9E2CFAE2

Key Words: Acanthomorpha, Late Cretaceous, Western Interior Seaway

\section{INTRODUCTION}

Acanthomorpha was the term coined by Rosen (1973) to group the Paracanthopterygii and Acanthopterygii together with two fossil genera Ctenothrissa Woodward 1899 and Aulolepis Agassiz 1844, forming the largest group of teleost fishes. Since that time, differing compositions and interrelationships have been sporadically proposed for the group, but the composition of the acanthomorph subgroups and the interrelationships among them are still not satisfactorily determined. The origin and relationships of acanthomorph fishes have recently engendered renewed interest with several studies recently published or ongoing by several different groups of researchers. Most recently, Davesne et al. (2014) and Chen et al. (2014) published differing hypotheses within a few months of each other. Davesne et al. (2014) focused on the lampridiforms and their potential fossil members. Their analysis of osteological data from both extant and extinct taxa resulted in Polymixia being the sister group to the Paracanthopterygii plus Acanthopterygii (the latter

Published 5 February, $2016 \odot 2016$ by the author submitted August 21, 2015; revisions received January 28, 2016; accepted February. 1, 2016. Handling editor: Jordan Mallon. represented by a single beryciform in their analysis), with the Lampridiformes being the sister group to this group (= Euacanthomorpha, comprising Paracanthopterygii + Acanthopterygii + Polymixia). Chen et al. (2014) used mitochondrial and nuclear gene markers in their analysis which resulted in Polymixia placed as the sistergroup to the Paracanthopterygii (comprising Percopsiformes, Zeiformes and Gadiformes), with the Paracanthopterygii plus Polymixia together forming the sistergroup to the Acanthopterygii. In essence, the two studies differed in the placement of Polymixia, with Davesne et al. (2014) placing the genus as sister to paracanthopterygians plus acanthopterygians, and Chen et al. (2014) finding Polymixia to be the sistergroup of paracanthopterygians to the exclusion of the acanthopterygians. Grande et al. (2013) also found Polymixia to be the sistergroup only to the Paracanthopterygii; however, they found the Lampridiformes to be either the sistergroup to the Acanthopterygii alone or to all the rest of the Acanthomorpha (Acanthopterygii + Paracanthopterygii + Polymixia) depending on the type of analysis performed on their data.

Polymixia has been identified as the extant taxon that is key to our understanding of acanthomorph relation- 
ships (e.g., Borden et al. 2013; Grande et al. 2013).

Unfortunately, it is the only extant genus of the order, with the other members being enigmatic fossils from Cretaceous deposits around the world. The greatest diversity of the order is extinct, with members known for many decades that inhabited the Tethys Sea in the east (preserved in deposits of Lebanon, Dalmatia and as far west as the English Chalk) and from the Western Interior Seaway (from Alberta, Canada and Utah, USA).

The number of fossil acanthomorphs known has recently increased significantly with new species described from throughout the Western Interior Seaway and Tethys Sea in the last decade. These include, among others, Mubichthys cordobai, Pseudomonocentris microspinosus, Handuichthys interopercularis, Pepemkay maya and Zoqueichthys carolinae from Mexico (González-Rodríguez and Fielitz 2008; Alvarado-Ortega and Than-Marchese 2012, 2013; González-Rodríguez et al. 2013), Aspesaipichthys cavaensis from Italy (Taverne, 2004), Errachidia pentaspinosa, Homalopagus multispinosus, Magrebichthys nelsoni and an unnamed form from Morocco (Murray and Wilson 2014), as well as two previously reported from the Lac des Bois locality, Boreiohydrias dayi and an unnamed form (Murray and Cumbaa, 2013).

All these early acanthomorphs are fairly small in size, possibly indicating they would have had a restricted ability to migrate. They are also found in areas that had relatively shallow waters. These new finds increase the distribution of these fishes in the Eastern Tethys, from the east and north to the southwest (Morocco), in the Western Interior Seaway from central areas to the extreme north (Arctic Canada), and into the Western Tethys (Mexico). The new acanthomorph described here is from the northernmost known locality, Lac des Bois, situated just north of the Arctic Circle in the Northwest Territories, Canada.

\section{MATERIALS AND METHODS}

The Lac des Bois locality is situated in a remote area of the Northwest Territories of Canada, north of Great Bear Lake. Access to the site is by float plane (to land on the lake) with a trip of just under an hour from the nearest large settlement (Norman Wells, NT). Because of the expense of getting to the locality, only two fossil-collecting trips have been made since the site was discovered by petroleum geologists in 1968: the first in 1969 and the second in 2010. In 1969, fossils were collected from concretions that were in situ in the outcrop or that had fallen on the lake shore. In 2010, it was discovered that the shales along the water edge also contained fossils; this material is better preserved. Among the fossils collected from these shales is the single specimen of a new acanthomorph described here. It is preserved as an almost complete fish on one slab, missing only the posterior-most tip of the caudal dorsal fin rays (Fig. 1A). The anterior part of the fish is also preserved in counterpart (Fig. 2). A silicone peel was made of the more complete part (Fig. 1B). The specimen was photographed using a Nikon DCM1200C digital camera mounted on a Zeiss Discovery V8 stereo microscope under polarized light. The silicone peel was coated with ammonium chloride before being photographed under normal light. The material is catalogued in the collections of the University of Alberta Laboratory for Vertebrate Palaeontology (UALVP).

Anatomical Abbreviations: aa, anguloarticular; brst, branchiostegal rays; cc, compound centrum (presumed first preural and first ural centra); ch, ceratohyal; cl, cleithrum; cor, coracoid; den, dentary; end, endopterygoid; ep 1-3, epurals 1-3; epi, epioccipital; fr, frontal; hy 1-3, hypurals 1-3; hyo, hyomandibula; i, interopercle; io 2-3, infraorbirtal 2-3; 1, left; lac, lacrimal; le, lateral ethmoid; met, metapterygoid; mx, maxilla; op, opercle; pa, parietal; pcl, postcleithrum; pg, pelvic girdle; phy, parhypural; pmx, premaxilla; pop, preopercle; psph, parasphenoid; pto, pterotic; ptt, posttemporal; pu2, second preural centrum; qu, quadrate; r, right; ret, retroarticular; scl, supracleithrum; sm, supramaxilla; soc, supraoccipital; sop, subopercle; sym, symplectic; u, ural centrum with associated uroneural; un, uroneural associated with compound centrum.

\section{TAXONOMIC PLACEMENT}

The new taxon described below is placed in the Acanthomorpha based on presence of true (unsegmented, bilaterally fused) spines in the dorsal and anal fins (Johnson and Patterson 1993), presence of a haemaxanal complex (Blot 1969), thoracic position of the pelvic girdle (Taverne 2011), and pelvic fin rays numbering seven (Otero and Gayet 1996). It can be further assigned to the Polymixiiformes, because there are 18 principal rays $(\mathrm{i}, 8,8, \mathrm{i})$ in the caudal fin [instead of $19(\mathrm{i}, 9,8, \mathrm{i})$ ] and a long (full) neural spine on the second preural centrum (Patterson 1968).

Several extinct taxa have been placed in the Polymixiiformes that are here treated as families following Murray and Wilson (2014): Dalmatichthyidae, Dinopterygidae, and Pycnosteroididae; an additional extinct family, Boreiohydriidae, was erected by Murray and Cumbaa (2013). These families are monotypic, with a single species each, with the exception of Pycnosteroididae to which a second species was recently added (Murray and Wilson 2014). The type family for the order, Polymixiidae, contains both fossil and living species. 

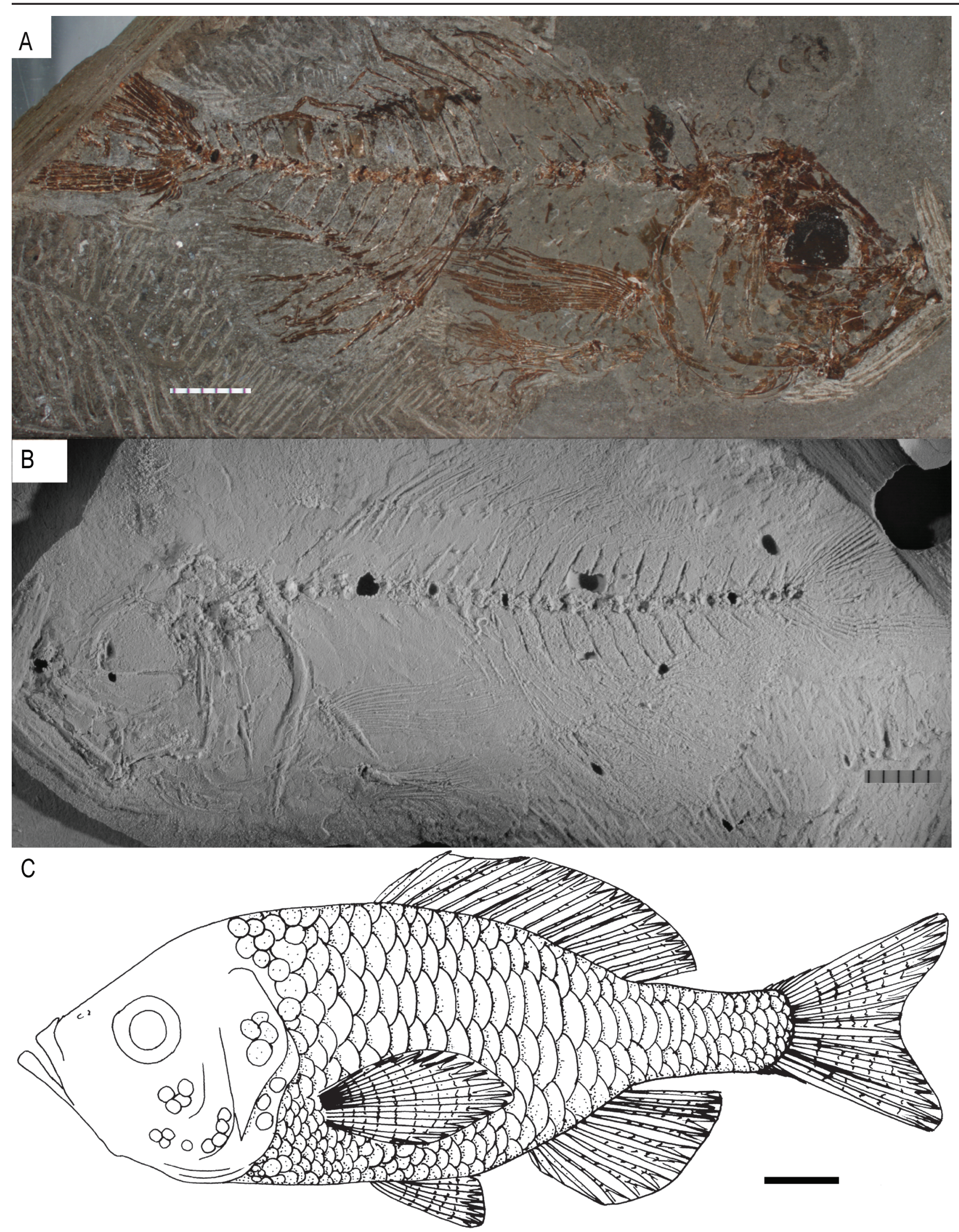

Figure 1. Cumbaaichthys oxyrhynchus gen. et sp. nov., UALVP 56113. A, Photograph of the complete specimen under polarized light; $B$, a silicone peel of the specimen coated with ammonium chloride; $C$, reconstruction of the whole fish including squamation; the true shape of the tail cannot be determined. Scale bar equals $5 \mathrm{~mm}$. 


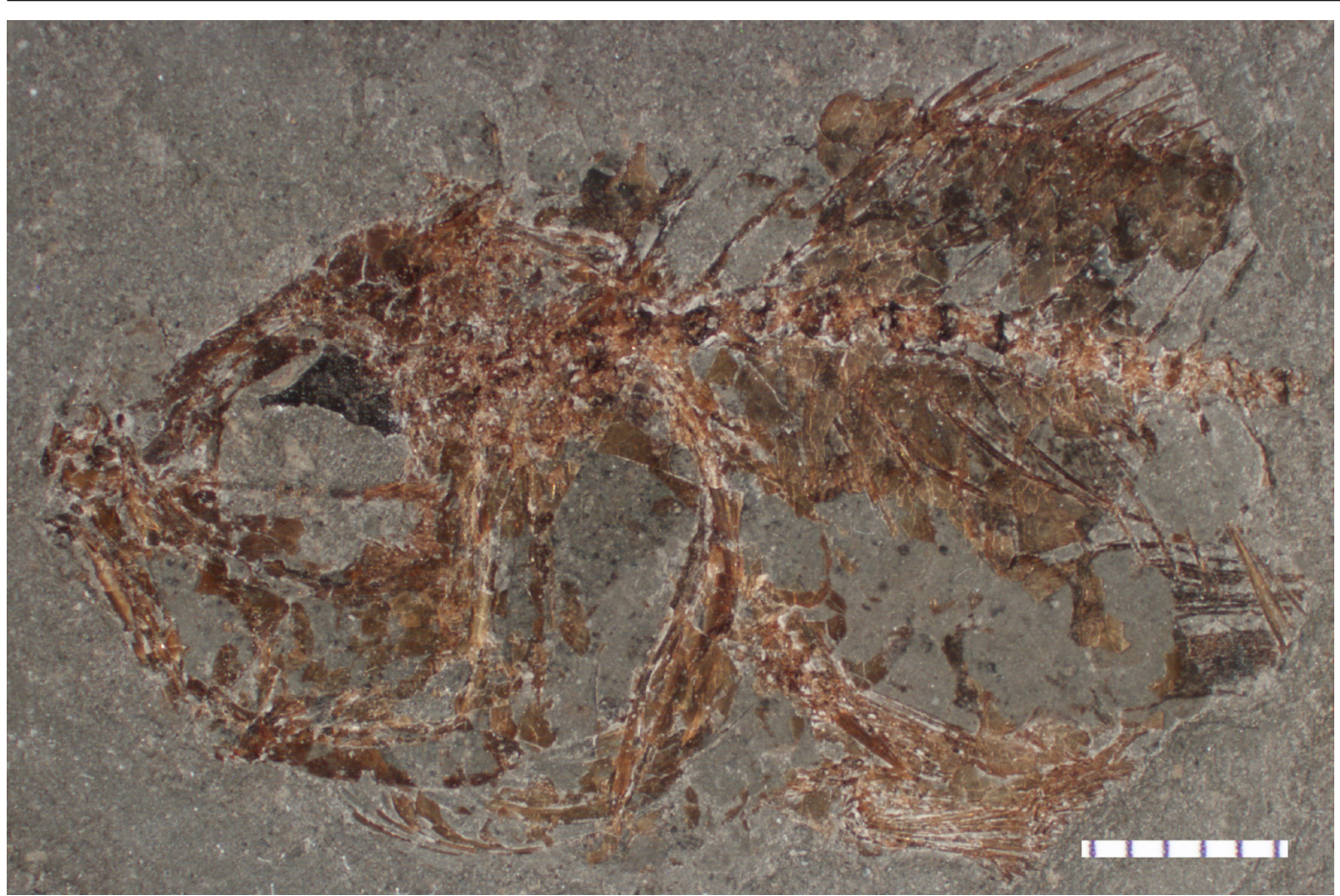

Figure 2. Cumbaaichthys oxyrhynchus gen. et sp. nov., UALVP 56113. Photograph of the counterpart under polarized light. Scale bar is in mm units.

Dalmatichthyidae was erected at the same time as the only genus and species, Dalmatichthys malezi Radovčić 1975, based on a single, not very well preserved specimen. This fish has a dorsal fin with eleven well-spaced spines, and five spines in the anal fin (Radovčić 1975; pers. obs.), more in both fins than the new taxon (with three spines in each). In common with the new taxon, Dalmatichthys has 26 vertebrae (Radovčić 1975; pers. obs.).

Dinopterygidae Jordan 1923 contains only Dinopteryx Woodward 1901, with the single species D. spinosis originally described by Davis (1887) in the genus Hoplopteryx Agassiz 1838. Patterson (1964) diagnosed this fish by having a dorsal fin with 15 spines and nine soft rays, and an anal fin with seven spines and nine soft rays, again many more spines in both fins than the new species. This taxon is based on only two poorly preserved specimens lacking details of the head and caudal skeleton. The well-spaced dorsal fin spines are reminiscent of those of Dalmatichthys (Patterson 1964:fig. 79). Dinopteryx has 27 vertebrae (Patterson 1964).

Pycnosteroididae was erected by Patterson (1964) for the single species Pycnosteroides levispinosus previously described by Hay (1903) and assigned to the genus by Woodward (1942), to which family Murray and Wilson (2014) added a second genus and species (Magrebichthys nelsoni). Members of this family have a spine in the pelvic fin $(i, 6)$ and a caudal fin formula of i, 8,8,i. In addition to these two characters, the emended diagnosis for this family from Murray and Wilson (2014) includes a dorsal fin with seven to nine spines, anal fin with three or four spines, and 25 to 27 vertebrae. The number of dorsal fin spines and the presence of a spine in the pelvic fin exclude the new Lac des Bois polymixiiform from this family.

The Boreiohydriidae, diagnosed as for the species based on the single specimen known (Murray and Cumbaa 2013), has 36 vertebrae, small spinoid scales, and seven dorsal fin spines, all of which differ from the condition found in the new species. The new taxon shares with Boreiohydrias the lack of teeth on the endopterygoid, two supraneurals, and a rather fusiform shape, although Boreiohydrias has a relatively smaller head compared to body size than the new taxon.

The new acanthomorph is more similar in the number of vertebrae to Dalmatichthyidae, Pycnosteroididae and Dinopterygidae (range of 25-27), rather than Boreiohydriidae which has about one third more vertebrae than the other families (total =36). However, it can be excluded from all these extinct families based on the numbers of spines and soft rays in the dorsal and anal fins.

All the extant members of the Polymixiidae are placed in a single genus, Polymixia Lowe 1838. The Cretaceous members of the family are separated into a number of genera (following Taverne 2011, and Murray and Wilson 2014): Berycopsis Dixon 1850, Berycopsia Radovčić 1975, Homonotichthys Whitley 1933, Omosoma Costa 1857, Omosomopsis Gaudant 1978, Pycnosterinx Heckel 1849, and Apricenaichthys Taverne 2011. The characters used to separate these fishes into separate genera (e.g., Patterson 1964; Taverne 2011) are a mixture of presumed primitive and derived characters, and the relationships among these genera are unclear. Although the family Polymixiidae as conceived by Patterson (1964) is co-extensive with 
Polymixiiformes, as used here, the diagnosis for the family given by Patterson (1964:263) is still more or less applicable at the family level, although the ranges for some meristic features are probably broader than necessary. His diagnosis included: long anal and dorsal fins with 4-11 spines in the dorsal and 3 or 4 in the anal fin; posteriorly expanded maxilla with two supramaxillae; scales partially or completely covering the opercle; eight or fewer branchiostegal rays; long high supraoccipital crest thickened centrally; enlarged first anal fin pterygiophore; 6-8 rays in the thoracic or sub-thoracic pelvic fin; and 26-34 vertebrae. Polymixiids also share the presence of two or three supraneurals (Patterson 1964; Radovčić 1975; Gaudant 1978; Taverne 2011), although this condition is also found in some of the other members of the order (e.g., Murray and Wilson 2014; Murray and Cumbaa 2013). The new acanthomorph has only three spines in the dorsal fin, but otherwise fits this diagnosis. However, as noted the diagnosis is very broad for a family, and encompasses much of the variation seen in the order.

The new taxon cannot be confidently placed in any of the previously described families, and might be given its own family. Alternately, instead of proliferating family names for monotypic taxa, it might fit best within Polymixiidae, if the range of dorsal fin spines for that family is expanded. However, the new genus is here left incertae sedis in the order because all these Cretaceous polymixiiforms and acanthomorphs need a more comprehensive analysis of relationships.

\section{SYSTEMATIC PALAEONTOLOGY}

Sept ACANTHOMORPHA Rosen 1973 (sensu Johnson and Patterson 1993)

Order POLYMIXIIFORMES Lowe 1838

incertae sedis

Cumbaaichthys gen. nov.

Type and Only Known Species: Cumbaaichthys oxyrhynchus sp. nov.

Etymology: The generic name is in honour of Stephen L. Cumbaa, for his significant contribution to our understanding of the Canadian fossil ichthyofauna through his field work, including at Lac des Bois, and publications on vertebrates including fishes and faunas of Canada. The ending, ichthys, is Greek for fish, gender masculine.

Diagnosis: as for type and only known species.

Cumbaaichthys oxyrhynchus sp. nov.

Figures 1-4

Holotype: UALVP 56113, an almost complete fish, missing only the posteriormost tip of the fin rays of the dorsal lobe of the caudal fin, with a counterpart for the anterior portion.

Diagnosis: A polymixiiform fish based on having 18 principal caudal fin rays (formula i, $8,8, i$ ) and a full neural spine on the second preural centrum; differs from all other polymixiiform (and basal acanthomorph) fishes by the following combination of characters: two supraneurals (dorsal formula $0 / / 0+2+1 /)$; pelvic fin with seven rays and no spine and three spines in the dorsal fin. Further distinguished from other Cretaceous acanthomorphs by: fusiform shape with a body depth of about 39\% of standard length [unlike the deep-bodied aipicthyoids]; endopterygoid lacks teeth [unlike most polymixiiforms, but similar to the other polymixiiform from the same locality Boreiohydrias dayi].

Type Locality and Horizon: GSC locality 84342 , Lac des Bois, Northwest Territories, Canada, approximately $66^{\circ} 52^{\prime} \mathrm{N}, 125^{\circ} 22^{\prime} \mathrm{W}$; based on invertebrates the age is early Turonian (Cook and Aiken, 1971; Yorath and Cook, 1981).

Etymology: The specific epithet is from the Greek words rhynchos, meaning snout or muzzle, and oxy, meaning tapering to a point, in reference to the snout of the fish being rather pointed in lateral view, unlike many other polymixiiforms (e.g., the extant Polymixia or extinct Boreiohydrias and Apricenaichthys) in which the snout is very rounded in lateral view.

\section{Description}

General Body Form: This is a fusiform fish, but the head is large in relation to body (Fig. 1) compared to the other named acanthomorph from Lac des Bois, Boreiohydrias dayi. The specimen measures $65.6 \mathrm{~mm}$ from the tip of the premaxilla to the end of the preserved portion of the forked caudal fin, and the complete fish would likely not have been much longer. The standard length (SL) is $55.2 \mathrm{~mm}$. The head length is $19.6 \mathrm{~mm}(35 \% \mathrm{SL})$ and it is only slightly less deep than long $(17.6 \mathrm{~mm})$. The greatest body depth is at the origin of the dorsal fin, and measures $20.4 \mathrm{~mm}$ (37\% SL). The jaws are preserved slightly open, but it is still clear that the profile of the snout is almost pointed, not blunt as in B. dayi or Polymixia.

Skull: The bones of the skull are somewhat crushed but some details can be determined (Fig. 3). The frontal is long and of uniform width anteriorly, but broadens posteriorly at the posterior end of the orbit. The groove for the sensory canal can be seen posteriorly where it branches medially towards the other frontal and laterally towards the pterotic, and it appears the canal was enclosed by bone. The limits of the parietal and supraoccipital are not clear, but it appears that the supraoccipital extended anteriorly to a level over the posterior half of the orbit, separating the parietals in the midline (lateroparietal condition). The limits of the pterotic 

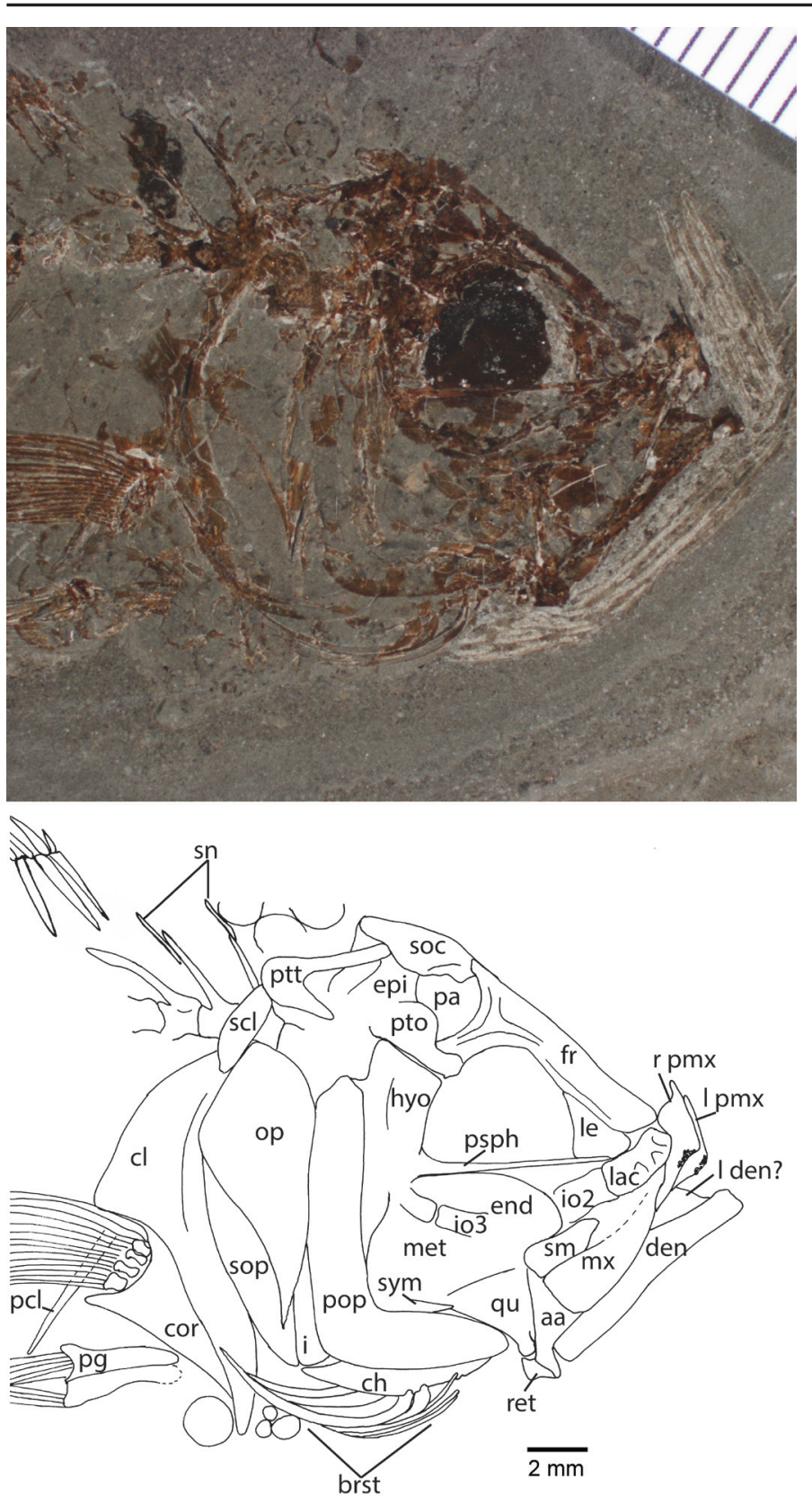

Figure 3. Cumbaaichthys oxyrhynchus gen. et sp. nov., UALVP 56113. Top, Photograph of the head, pectoral and pelvic girdles under polarized light; bottom, interpretive drawing. Scale bar equals $2 \mathrm{~mm}$.

are also not clear, but it appears to have had a large dorsal portion, and a broad ventral edge meeting the hyomandibula. The lateral ethmoid, visible in the anterior portion of the orbit, is large and reaches the parasphenoid. This latter bone is narrow in lateral view and broadens slightly posteriorly at the posterior extent of the orbit.

Jaws: The jaws are fairly long, with the articulation of the anguloarticular and quadrate positioned under the anterior third of the orbit. The mouth is upturned, giving the snout its pointed profile. Teeth are visible on both left and right premaxillae (Fig. 3), but are not preserved on the dentary. The limits of the maxilla and supramaxillae are obscured by remains of crushed bone. The premaxilla appears to be about half the length of the maxilla. In the lower jaw, a separate retroarticular contributes to the articular facet for the quadrate.

Circumorbital Bones: The lacrimal (Fig. 3) is rectangular and bears the branched sensory canal. Posterior to this, bone fragments indicate more circumorbital bones would have been present but their limits are unclear; however, the remains indicate the circumorbital bones were fairly narrow, and did not cover much of the cheek region.

Opercular Bones: The opercle overall is more than twice as high as it is wide. It narrows ventrally to a sharp point (Fig. 3). A large subopercle underlies the opercle and reaches dorsally almost as far as the preopercle. Anteroventrally the subopercle meets the interopercle which is mostly obscured by the overlying bones. The two limbs of the preopercle form a right angle, with the horizontal limb less than three quarters of the length of the vertical limb. There are no spines or ornamentation visible on any of the opercular bones.

Suspensorium and Branchial Bones: The hyomandibula (Fig. 3) has a broad, single head. The ventral portion is obscured, as is most of the symplectic. The metapterygoid is not well-preserved, but would likely have been fairly large based on the amount of space available for it. The endopterygoid reaches the parasphenoid dorsally and there is no evidence of endopterygoid teeth. The anterior and posterior edges of the triangular quadrate form an angle of less than 90 degrees.

The anterior ceratohyal is long and thin, and has no beryciform foramen visible (Fig. 3). There are eight branchiostegal rays, of which the first three are narrower than the rest, but not modified as in Polymixia. All are acinaciform.

Axial Skeleton: There are 26 vertebrae (Fig. 1) including the compound centrum and free ural centrum [presumed fused first preural and first ural centra (pu1+u1) and second ural centrum (u2)] of which 10 are in front of the first anal pterygiophore (abdominal centra). All vertebral centra are longer than high and of similar size throughout the column except for the posteriormost three centra (pu2, pu1+u1, and $\mathrm{u} 2$ ) which are progressively smaller. No intermuscular bones are preserved, and only the posterior few ribs are preserved.

Paired Fins and Girdles: The posttemporal has a dorsal limb articulating with the skull roof that is about twice as long as the ventral limb (Fig. 3). The supracleithrum is smaller and oval in shape. The cleithrum curves gently from the pointed ventral tip to the broader dorsal plate. Although the coracoid and scapula are not very clear, there are four squat radials visible supporting the fin rays (Fig. 3). The pectoral fin is situated closer to the ventral edge of the 
body than to the vertebral column. It is formed by 16 rays. A strong rod-like postcleithrum reaches past the posterior end of the pelvic girdle (Fig. 3).

The pelvic fin is thoracic, positioned almost as far anteriorly as the pectoral fin (Figs. 1-3). The left and right halves of the pelvic girdle meet in the midline. There are seven rays in each pelvic fin, and no spines. Both the pectoral and pelvic fins are fairly long, with the pectoral reaching posteriorly to the level of the anal fin origin, and the pelvic rays not quite reaching the anal fin origin.

Dorsal and Anal Fins: The dorsal fin base (Fig. 1) is fairly long $(19.9 \mathrm{~mm}, 36 \% \mathrm{SL})$, with the origin dorsal to the level of the pelvic girdle, and reaching almost to the start of the caudal peduncle. The dorsal fin contains three spines and 17 rays, and is supported by at least 17 pterygiophores. The anal fin base $(8.8 \mathrm{~mm}, 16 \% \mathrm{SL})$ is less than half the length of the dorsal fin base. The anal fin is composed of three spines and probably 10 rays; the rays are somewhat disarticulated making the count uncertain. There are 11 anal fin pterygiophores, with the first one supporting the first two fin spines. The first and second anal fin pterygiophores contact the anterior edge of the first haemal spine to form a haemaxanal complex. The pterygiophores reach about one third of way along the length of the haemal spine, forming the Type II complex of Blot (1969) that is diagnostic for acanthomorphs.

Predorsal Formula: There are two supraneurals preserved, in very close association with the neural spines, causing them to be difficult to discern. The proximal end of the first supraneural lies along the anterior edge of the first neural spines and the second supraneural lies along the posterior edge of the second neural spine (Fig. 3). The first two dorsal fin pterygiophores insert between the neural spines of the second and third centra, and the first pterygiophore supports two spines. The next two pterygiophores insert between the third and fourth neural spines; posteriorly there is a one to one relationship between the alternating pterygiophores and neural spines. Therefore, the predorsal formula in C. oxyrhynchus, is $0 / / 0+2+1 / 1+1 / 1 / 1$.

Caudal Fin: The caudal fin (Fig. 4) has 18 principal rays (16 branched), and six dorsal and six ventral procurrent rays. There is a full neural spine on the second preural centrum. Two long uroneurals are present as well as three epurals. The compound centrum (presumed first preural + first ural centra) has a small neural arch and bears the parhypural and two hypurals. Four more hypurals are present in the upper fin lobe for a total of six hypurals. The shape of the tail fin cannot be determined.

Scales: Large cycloid scales are present and well preserved on the anterior part of the body with nine or 10 in a transverse row just posterior to the cleithrum (Fig. 1). Remains and impressions of eight scales are preserved be-
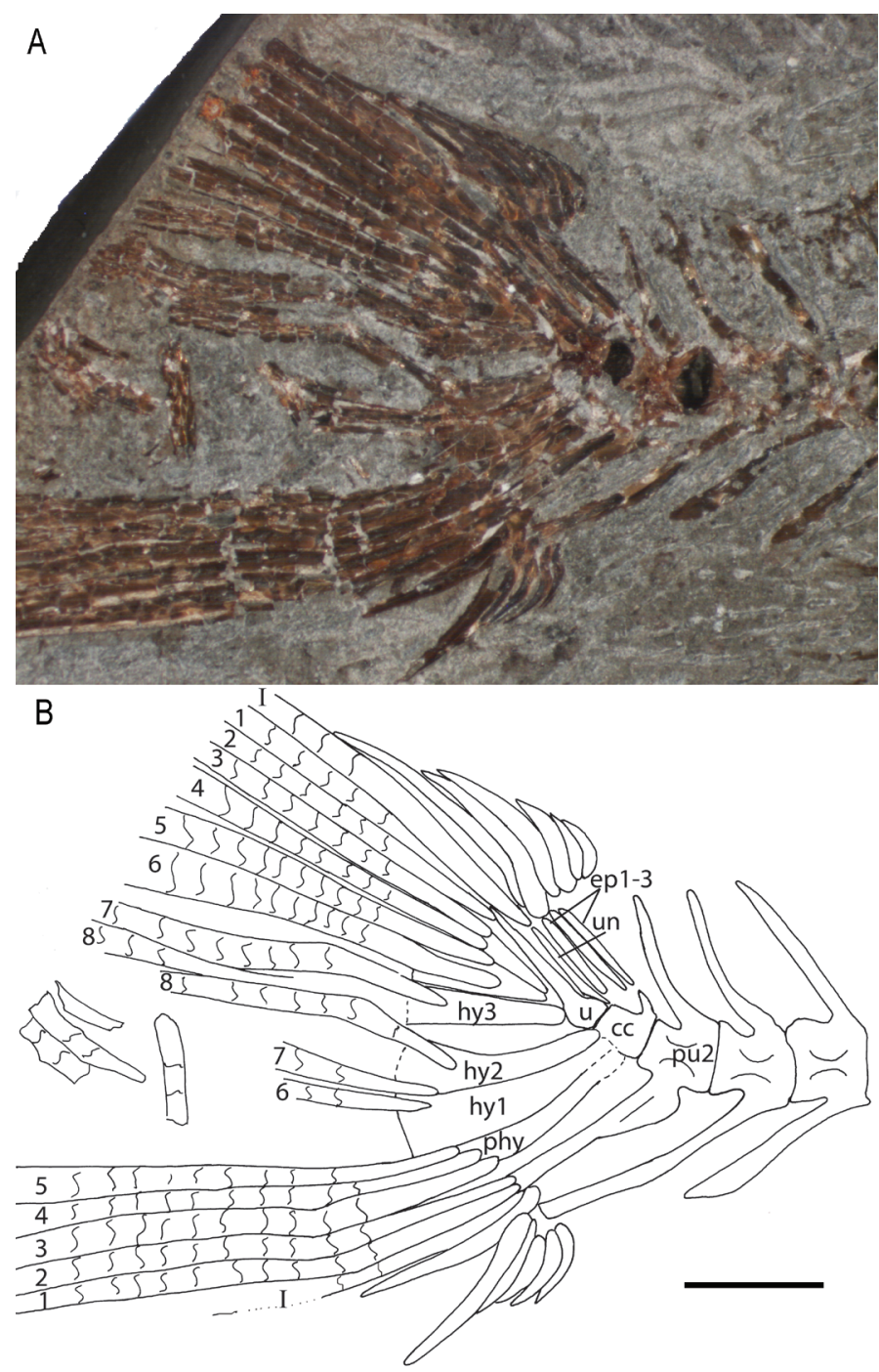

Figure 4. Cumbaaichthys oxyrhynchus gen. et sp. nov., UALVP 56113. A, Photograph of the caudal skeleton under polarized light; $B$, interpretive drawing and indication of principal fin ray count. Scale bar equals $2 \mathrm{~mm}$.

tween the posterior edge of the cleithrum and the anterior anal fin pterygiophores; based on the size of these, and assuming the scales would become progressively slightly smaller posteriorly, there would have been an estimated 21 or 22 lateral line scales. The scales are higher than wide, with a posteriorly positioned oval focus and 40 to 42 circuli. Cycloid scales are also present ventrally in front of the pelvic fins; these are somewhat smaller than the body scales. Smaller cycloid scales are also present on the opercle, preopercle, cheek, and supraoccipital but none are preserved on the frontal bones.

\section{DISCUSSION}

Cumbaaichthys oxyrhyncus is included in the

Polymixiiformes, based on the caudal fin with 18 principal rays and a full spine on the second preural centrum. 
The relationships among the families and genera assigned to the polymixiiforms are in need of much study; however, such a study is part of a larger project by $\mathrm{T}$. Grande and colleagues, therefore, it will not be addressed here. Polymixiiform relationships are also under study by other ichthyologists, either directly or as a part of larger studies on Acanthomorpha (e.g., G. Lecointre and colleagues - http://Acanthoweb.fr). Therefore, the relationships of Cumbaaichthys oxyrhynchus are left undetermined here, until such time as new information may become available.

\section{Early Fossil Record of Acanthomorpha}

The oldest reported acanthomorph fossils (Appendix 1) include six species from Albian-Cenomanian or earliest Cenomanian deposits of North America. Two of these, Dalgoichthys tropicalis and Mubichthys cordobai from the Albian-Cenomanian El Doctor Formation of south-central Mexico, are placed in the Acanthomorpha, but in uncertain position (González-Rodríguez and Fielitz 2008; GonzálezRodríguez et al. 2013). The other two, Pseudomonocentris microspinosus and Handuichthys interopercularis from the same locality, are the only members of the beryciform family Pseudomonocentrididae (González-Rodríguez et al. 2013). The final two of these six acanthomorphs, both from deposits considered to be earliest Cenomanian, are Xenyllion zonensis Wilson and Murray 1996 from the Fish Scales Formation (formerly known as part of the Shaftsbury Formation) of Alberta, and the closely related Xenyllion stewarti Newbrey et al. 2013 from the Mowry Formation of Utah. These two species are considered to be closely related to Sphenocephalus from the late Campanian of Westfalia, Germany, and are placed with that genus in the Sphenocephaliformes (Wilson and Murray 1996; Newbrey et al. 2013). Few other acanthomorphs have been reported from North America. Zoqueichthys carolinae, an aipichthyoid, and Pepemkay maya, considered to be a trachichthyid beryciform, are from deposits of the El Chango quarry of Mexico (Alvarado-Ortega and Than-Marchese 2012, 2013), that are now dated as early Cenomanian based on the ammonite assemblages (Moreno-Bedmar et al. 2014). Therefore, by the early Cenomanian, acanthomorphs were distributed throughout the waters of the proto-Gulf of Mexico and Western Interior Seaway.

Three more acanthomorphs are known from the Turonian of North America: Boreiohydrias dayi and an unnamed taxon from northern Canada (Murray and Cumbaa 2013), and an unnamed holocentroid from Kansas (Stewart 1996). The rest of the Late Cretaceous North American acanthomorph skeletal fauna is from the late Santonian of Kansas (Kansius sternbergi, Caproberyx sp., Omosoma garretti), Campanian of Texas (Hoplopteryx lewesiensis) and Maastrichtian of New Jersey (?Hoplopteryx insculptus) (Cockerell 1919; Bardack 1976; Bardack and TellerMarshall 1982; Stewart 1996).

In contrast to the North American record, which has relatively few named acanthomorphs representing fishes living in the Mowray Sea or (later) Western Interior Seaway (Canada and the United States) or the Western Tethys (Mexico), there are many more species of acanthomorphs in the Late Cretaceous of the Eastern Tethys (southern Europe, northern Africa and the Levant). The earliest known from the Eastern Tethys are of Cenomanian age (Appendix 1). Despite the much greater numbers of species known from the Eastern Tethys, the higher-level diversity of the two areas is similar, with aipichthyoids, polymixiiforms, sphenocephaliforms and beryciforms found in both the east and west (Appendix 1). The tetraodontiforms are the only higher-level group found in the east that have not yet been found in the west. A number of authors have noted the much higher numbers of acanthomorph species in the Western Tethys compared to North America (e.g., Bardack and Teller-Marshall 1982; Stewart 1996). With new information on acanthomorphs coming from new discoveries in Mexico (e.g., Alvarado-Ortega and ThanMarchese 2012, 2013; González-Rodríguez et al. 2013) and Canada (e.g., Murray and Cumbaa 2013), the North American record may eventually prove to be as rich as that of the Eastern Tethys.

Newbrey et al. (2013) suggested that the increased diversity of acanthomorphs starting in the Cenomanian might be a factor of their small size associated with a warming trend. They postulated that the Cenomanian-Turonian Thermal Optimum was beneficial for small-bodied animals that would be expected to have higher metabolic rates and faster generation turn-over times. These species would have higher diversification during times of warmer climates (Newbrey et al. 2013). Cavin et al. (2007) also reported a positive correlation between diversity of acanthomorph fishes and sea temperature. Whether or not this is correct, species diversity of acanthomorphs is much lower in the Turonian compared to the Cenomanian. In fact, the highest number of described species is for the Cenomanian (with 41 named species; Appendix 1). The numbers of species known in each time slice is at least partly dependent on the availability of fossil localities of appropriate ages and preservation, and may not be correlated with actual numbers of fishes that were present in the Late Cretaceous seas. Additionally, each time slice (stage) is not of the same duration, which adds to the difficulty of comparing diversity over time. However, with the data compiled in Table 1, it is now easier to compare number of species or genera during the early radiation of Acanthomorpha. 


\section{ACKNOWLEDGEMENTS}

Field work for this project was funded by the Polar Continental Shelf Program (to S.L. Cumbaa), the Canadian Museum of Nature (S.L. Cumbaa), and Natural Science and Engineering Research Council of Canada Discovery Grant 327448 (AMM). Fieldwork was conducted under Aurora Research Institute Scientific Research Licence \#14714 issued to S.L. Cumbaa. Thanks to S.L. Cumbaa, R. Day (both CMN) and R.B.Holmes (CMN \& UALVP) for collecting material from Lac des Bois, and companionship in the field. Thanks also to D. Bardack, T. Grande and M.V.H. Wilson for providing access to comparative acanthomorph material in their care, and to $\mathrm{O}$. Otero, J. Alvaredo-Ortega and M.N. Newbrey for providing helpful reviews on various versions of the manuscript.

\section{LITERATURE CITED}

Agassiz, L. 1838. Chapter XVII. Du genre Hoplopteryx; pp. 151-152, in Recherches sur les poisson fossils, Vol. 4. De l'Ordre des Cténoides. Neuchatel.

Agassiz, L. 1844. Chapter IV. Des genres Acrognathus et Aulolepis Agass; pp. 108-110, in Recherches sur les poisson fossils, Vol. 5, part II. Des Cycloides Malacoptérygien. Neuchatel.

Alvarado-Ortega, J., and B.A. Than-Marchese. 2012. A Cenomanian aipichthyoid fish (Teleostei, Acanthomorpha) from America, Zoqueichthys carolinae gen. et sp. nov. from El Chango quarry (Cintalapa Member, Sierra Madre Formation), Chiapas, Mexico. Revista Mexicana de Ciencias Geológicas 29:735-748.

Alvarado-Ortega, J., and B.A. Than-Marchese. 2013. The first record of a North American Cenomanian Trachichthyidae fish (Acanthomorpha, Acanthopterygii), Pepemkay maya, gen. et sp. nov., from El Chango quarry (Sierra Madre Formation), Chiapas, Mexico. Journal of Vertebrate Paleontology 33:48-57.

Bardack, D. 1976. Paracanthopterygian and acanthopterygian fishes from the Upper Cretaceous of Kansas. Fieldiana Geology 33:355-374.

Bardack, D., and S. Teller-Marshall. 1982. First Cretaceous specimens of the beryciform fish Hoplopteryx from North America and their bearing on acanthopterygian evolution. The PearceSellards Series, Occasional Publication of the Texas Memorial Museum, University of Texas at Austin 34:1-14.

Blot, J. 1969. Studi e ricerche sui Giacimenti Terziari di Bolca. Les poissons fossiles du Monte Bolca. Museo Civico di Storia Naturale di Verona Memorie Fuori serie 2, 525 pp.

Borden, W.C., T. Grande, M.V.H. Wilson, and A.M. Murray. 2013. Search for the basal acanthomorph fish: an interdisciplinary approach to revising polymixiiforms and understanding the origin of spiny-rayed fishes. 6th International Meeting on Mesozoic Fishes, Diversification and Diversity Patterns, 4-10 August 2013, Vienna, Austria. Abstract volume p. 11.
Cavin, L., P.L. Forey, and C. Lécuyer. 2007. Correlation between environment and Late Mesozoic ray-finned fish evolution. Palaeogeography, Palaeoclimatology, Palaeoecology, 245:353-367.

Chen, W.-J., F. Santini, G. Carnevale, J.-N. Chen, S.-H. Liu, S. Lavoué, and R. L. Mayden. 2014. New insights on early evolution of spiny-rayed fishes (Teleostei: Acanthomorpha). Frontiers in Marine Science 1(53):1-17. doi 10.3389/fmars.2014.00053

Cockerell, T.D.A. 1919. Some American Cretaceous fish scales, with notes on classification and distribution of Cretaceous fishes. United States Geological Survey Professional Paper 120-I:165-202.

Cook, D.G., and J.D. Aitken. 1971. Geology, Colville Lake map-area and part of Coppermine map-area Northwest Territories. Geological Survey of Canada, Paper 70-12, Ottawa, 42 pp.

Costa, O.G. 1857. Descrizione di alcuni pesci fossili del Libano. Memorie dell'Accademia reale di Scienze di Napoli, 2:97-112. [not seen]

Davesne, D., M. Friedman, V. Barriel, G. Lecointre, P. Janvier, C. Gallut, and O. Otero. 2014. Early fossils illuminate character evolution and interrelationships of Lampridiformes (Teleostei, Acanthomorpha). Zoological Journal of the Linnean Society 172:475-498.

Davis, J.W. 1887. The fossil fishes of the chalk of Mount Lebanon, in Syria. Scientific Transactions of the Royal Dublin Society 3:457-636.

Dixon, F. 1850. The geology and fossils of the Tertiary and Cretaceous formations of Sussex. F. Dixon, London, 422 pp. [not seen]

Gaudant, M. 1978. Contribution à une révision des poissons crétacés du Jbel Tselfat (Rides prérifaines, Maroc). Notes du Service Géologique Maroc 39:79-124.

González-Rodríguez, K.A., and C. Fielitz. 2008. A new species of acanthomorph fish from the Upper Cretaceous Muhi Quarry, Hidalgo, Central Mexico; pp. 399-411 in G. Arratia, H.-P. Schultze, and M.V.H. Wilson (eds.), Mesozoic Fishes 4 - Homology and Phylogeny. Verlag Dr. Friedrich Pfeil, München, Germany.

González-Rodríguez, K.A., H.-P. Schultz, and G. Arratia. 2013. Miniture armored acanthomorph teleosts from the Albian/ Cenomanian (Cretaceous) of Mexico; pp. 457-487 in G. Arratia, H.-P. Schultze, and M.V.H. Wilson (eds.), Mesozoic Fishes 5 - Global Diversity and Evolution,. Verlag Dr. Friedrich Pfeil, München, Germany.

Grande, T., W.C. Borden, and W.L. Smith. 2013. Limits and relationships of Paracanthopterygii: a molecular framework for evaluating past morphological hypotheses; pp. 385-418 in G. Arratia, H.-P. Schultze, and M. V. H. Wilson (eds.), Mesozoic Fishes 5 - Global Diversity and Evolution,. Verlag Dr. Friedrich Pfeil, München, Germany.

Hay, O.P. 1903. On a collection of Upper Cretaceous fishes from Mount Lebanon, Syria, with descriptions of four new genera and nineteen new species. Bulletin of the American Museum of Natural History, 19:395-452. 
Heckel, J.J. 1849. Die fossilen Fische des Libanon; pp. 336-346 in J. Von Russegger (ed.), Reisen in Europa, Asien und Afrika. Bd. II, thl: III. E. Schweizerbart, Stuttgart. [not seen]

Johnson, G.D., and C. Patterson. 1993. Percomorph phylogeny: a survey of acanthomorphs and a new proposal. Bulletin of Marine Science 52:554-626.

Jordan, D.S. 1923. A classification of fishes. Including families and genera as far as known. Stanford University Publications in Biological Sciences 3:79-243.

Lowe, R.T. 1838. Piscium Maderensium species quaedam novae, vel minus rite cognitae breviter descriptae, etc. Transactions of the Cambridge Philosophical Society 6:95-202. [not seen]

Moreno-Bedmar J.A., J.-L. Latil, U. Villanueva-Amadoz, L. Calvillo-Canadell, and S.R.S. Cevallos-Ferriz. 2014. Ammonite age-calibration of the EL Chango FossilLagerstätte, Chiapas state (SE Mexico). Journal of South American Earth Sciences 56:447-453.

Murray, A.M., and S.L. Cumbaa. 2013. Early Turonian acanthomorphs from Lac des Bois, Northwest Territories, Canada. Journal of Vertebrate Paleontology 33:293-300.

Murray, A.M., and M.V.H. Wilson 2014. Four new basal acanthomorph fishes from the Late Cretaceous of Morocco. Journal of Vertebrate Paleontology 34:34-48.

Newbrey, M.G., A.M. Murray, M.V.H. Wilson, D.B. Brinkman, and A.G. Neuman. 2013. A new species of the paracanthopterygian Xenyllion (Sphenocephaliformes) from the Mowry Formation (Cenomanian) of Utah, USA; pp. 363-384 in G. Arratia, H.-P. Schultze, and M.V.H. Wilson (eds.), Mesozoic Fishes 5 - Global Diversity and Evolution,. Verlag Dr. Friedrich Pfeil, München, Germany.

Otero, O., and M. Gayet. 1996. Anatomy and phylogeny of the Aipichthyoidea nov. of the Cenomanian Tethys and their place in the Acanthomorpha (Teleostei). Neues Jahrbuch fuer Geologie und Paläontologie Abhandlungen 202:313-344.

Patterson, C. 1964. A review of Mesozoic acanthopterygian fishes, with special reference to those of the English Chalk. Philosophical Transactions of the Royal Society, London series B, Biological Sciences 247:213-482.

Patterson, C. 1968. The caudal skeleton in Mesozoic acanthopterygian fishes. Bulletin of the British Museum (Natural History) Geology 17:49-102.
Radovčić, J. 1975. Some new Upper Cretaceous teleosts from Yugoslavia with special refernce to localities, geology and palaeoenvironment. Palaeontologia Jugoslavica 17:7-55.

Rosen, D. 1973. Interrelationships of higher euteleostean fishes; pp. 397-513 in P.H. Greenwood, R.S. Miles, and C. Patterson, (eds.), Interrelationships of Fishes. London (Academic Press).

Stewart, J.D. 1996. Cretaceous acanthomorphs of North America; pp. 383-394 in G. Arratia and G. Viohl (eds.), Mesozoic Fishes - Systematics and Paleoecology. Verlag Dr. Friedrich Pfeil, München, Germany.

Taverne, L. 2004. Les poissons crétacés de Nardò. $17^{\circ}$. Aspesaipichthys cavaensis gen. et sp. nov. (Teleostei, Acanthomorpha, Aipichthyoidea). Bollettino del Museuo Civico di Storia Naturale di Verona 28:3-15.

Taverne, L. 2011. Les poissons du Santonien (Crétacé supérieur) d'Apricena (Italie du Sud). 3º. Apricenaichthys italicus gen. et sp. nov. (Teleostei, Polymixiiformes). Bolletino del Museo Civico di Storia Naturale di Verona 35:19-31.

Whitley, G.P. 1933. New names for fossil fishes. Copeia 1933:146.

Wilson, M.V.H., and A.M. Murray. 1996. Early Cenomanian acanthomorph teleost in the Cretaceous Fish Scale Zone, Albian/Cenomanian boundary, Alberta, Canada; pp. 369-382 in G. Arratia, and G. Viohl (eds.), Mesozoic Fishes - Systematics and Paleoecology. Verlag Dr. Friedrich Pfeil, München, Germany.

Woodward, A.S. 1899. Note on some Cretaceous clupeoid fishes with pectinated scales (Ctenothrissa and Pseudoberyx). Annals and Magazine of Natural History, 7th series, 3:489-492.

Woodward, A.S. 1901. Catalogue of Fossil Fishes in the British Museum. The Trustees of the British Museum, London, volume 4, $406 \mathrm{pp}$.

Woodward, A.S. 1942. Some new and little-known Upper Cretaceous fishes from Mount Lebanon. Annals and Magazine of Natural History, 11th series 9:537-568.

Yorath, C.J., and D.G. Cook. 1981. Cretaceous and Tertiary stratigraphy and paleogeography, Northern Interior Plains, District of MacKenzie. Memoirs of the Geological Survey of Canada 398:1-76. 
Appendix 1. Named acanthomorph fishes from Late Cretaceous deposits. The list is based in part on Patterson (1993) and Friedman (2009 supplementary information) ${ }^{\mathrm{b}}$, with additional references as noted for each taxon.

\section{Taxon}

Acanthomorpha incertae sedis

Dalgoichthys tropicalis

Muhichthys cordobai

Gigapteryx tethyestris

Spinocaudichthys oumtkoutensis

Pharmacichthyidae

Pharmacichthys venenifer

P. numismalis

P. judensis

Aipichthyoidea

incertae sedis

Freigichthys elleipsis

Errachidia pentaspinosa

Homalopagus multispinosus

Paracentrus lebanonensis

Aipichthyidae

Paraipichthys lusitanicus

Aipichthys minor

A. velifer

A. nuchalis

A. oblongus

Aipichthyoididae

Aipichthyoides galeatus

A. formosus

Aspesaipichthys cavaensis

Zoqueichthys carolinae

Polymixiiformes

Polymixiidae

Apricenaichthys italicus

Berycopsis elegans

B. germanus

Berycopsia inopinnata

Homonotichthys dorsalis

H. pulchellus

H. rotundus

Omosoma sahelalmae

O. monasteri

O. pulchellum

O. intermedium

O. tselfatensis

O. croatica

O. garretti

Omosomopsis simum

Pycnosterinx russeggeri

P. discoides

P. gracilis

P. dubius

\section{Age, Country or Area}

Albian-Cenomanian, Mexico

\section{Reference}

Albian-Cenomanian, Mexico 21

Cenomanian, Lebanon $\quad 12$

Cenomanian, Morocco 11

Cenomanian, Lebanon $\quad 47$

Cenomanian, Lebanon 18

Cenomanian, Jerusalem 17

Cenomanian, Hajula 29

Cenomanian-Turonian, Morocco 27

Cenomanian-Turonian, Morocco 27

Cenomanian, Lebanon

Cenomanian, Portugal 15

Cenomanian, Lebanon $\quad 30$

Cenomanian, Lebanon 30

Cenomanian-Turonian, England 8

Cenomanian, Lebanon $\quad 30$

Cenomanian, Jerusalem $\quad 17,30$

Cenomanian, Jerusalem 17

Campanian-Maastrichtian, Italy 39

Cenomanian, Mexico 1
Santonian, Italy $\quad 40$

Cenomanian-Turonian, England 32

Campanian, Germany 32

Turonian, Croatia 35

Cenomanian-Turonian, England 32

Cenomanian-Turonian, England 32

Cenomanian-Turonian, England 32

Senonian, Lebanon 32

Senonian, Germany, Westphalia 32, 45

Santonian, Lebanon $\quad 32$

Santonian, Lebanon $\quad 32$

Cenomanian, Morocco 16

Turonian, Croatia 35

Santonian, Kansas USA $\quad 5,37$

Senonian, Morocco 3, 16

Santonian, Lebanon 32

Santonian, Lebanon $\quad 32$

Santonian, Lebanon $\quad 32$

Santonian, Lebanon $\quad 32$ 
Taxon

$$
\begin{aligned}
& \text { Dinopterygidae } \\
& \text { Dinopteryx spinosus } \\
& \text { Pycnosteroididae } \\
& \text { Pycnosteroides levispinosus } \\
& \text { Magrebichthys nelsoni } \\
& \text { Dalmatichthyidae } \\
& \text { Dalmatichthys malezi } \\
& \text { Boreiohydriidae } \\
& \text { Boreiohydrias dayi }
\end{aligned}
$$$$
\text { Age, Country or Area }
$$

Reference

$$
\begin{array}{lc}
\text { upper Senonian, Lebanon } & 32 \\
\text { Cenomanian, Lebanon } & 47 \\
\text { Cenomanian-Turonian Morocco } & 27 \\
\text { Senonian, Croatia } & 35 \\
\text { Turonian, Canada } & 26
\end{array}
$$

Campanian-Maastrichtian, Italy

Cenomanian, Portugal

Sphenocephaliformes

Sphenocephalidae

Sphenocephalus brachypterygius
S. fissicaudus
S. cataphractus
Xenyllion zonensis
X. stewarti

Campanian, Germany

Beryciformes

$$
\begin{aligned}
& \text { incertae sedis } \\
& \text { Plesioberyx maximus } \\
& \text { P. discoides } \\
& \text { Cryptoberyx minimus } \\
& \text { Cryptoberyx brevis } \\
& \text { Quaesitoberycidae } \\
& \text { Quaesitoberyx minutus } \\
& \text { Microcapros libanicus } \\
& \text { Pseudomonocentrididae } \\
& \text { Pseudomonocentris microspinosus } \\
& \text { Handuichthys interopercularis }
\end{aligned}
$$
Pseudomonocentris microspinosus
Handuichthys interopercularis

Trachyichthyoidei

$\begin{array}{ll}\text { Cenomanian, Lebanon } & 18 \\ \text { Cenomanian, Lebanon } & 18 \\ \text { Cenomanian, Lebanon } & 18 \\ \text { Cenomanian, Portugal } & 15 \\ & \\ \text { Cenomanian, Lebanon } & 4 \\ \text { Cenomanian, Lebanon } & 4,19 \\ \text { Albian-Cenomanian, Mexico } & 22 \\ \text { Albian-Cenomanian, Mexico } & 22\end{array}$

Cenomanian, Levant $\quad 17$

Cenomanian-Turonian, Lebanon $\quad 14$

Cenomanian, Lebanon 34, 38

Cenomanian, Lebanon 14, 38

Cenomanian, Lebanon $\quad 38$

Cenomanian, Morocco 16, 38

Campanian-Maastrichtian, Italy 38

Cenomanian, Komen 9, 23, 36

Cenomanian, Lebanon $\quad 17$

Campanian, Germany, Westphalia 34

Campanian, Germany, Westphalia 34, 43

Campanian, Germany, Westphalia 43, 44

Senonian, Lebanon 34

Senonian, Lebanon $\quad 20$

Senonian, Lebanon 33, 34

Campanian, Germany, Westphalia 34

$\begin{array}{ll}\text { Senonian, Lebanon } & 32,47\end{array}$

Late Cretaceous, Germany, Sedenhorst 43

Cenomanian-Turonian, England 34 
Taxon

H. lewisi

H. lewesiensis

H. macracanthus

H. gephyrognathus

H. syriacus

H. stachei

?Hoplopteryx (=Beryx) insculptus

Stichoberyx polydesmus ${ }^{\mathrm{d}}$

Lobopterus pectinatus

Hgulichthys spinus

Antarctiberyx seymouri

Tubantia cataphractus

Holocentroidei

Stichocentrus liratus

S. elegans

S. spinulosus

Alloberyx syriacus

A. (= Serratocentrus) robustus ${ }^{\mathrm{e}}$

Parospinus cupulus

Pattersonoberyx (= Caproberyx) pharsus

Caproberyx superbus type species

Caproberyx sp.

Ctenocephalichthys longispinus

C. lorteti

C. brevispinus

Erugocentrus illyricus

Adriacentrus crnolataci

Trachichthyoides ornatus

Pelotius hesselae

Pepemkay maya

Kansius sternbergi

Tetraodontiformes

\section{Age, Country or Area}

Cenomanian, Lebanon

Cenomanian-Turonian, England;

Turonian, Europe; Campanian, Texas

Cenomanian-Turonian, England

Cenomanian-Turonian, England

Santonian, Lebanon

Cenomanian, Komen

Maastrichtian, USA, New Jersey

Cenomanian, Morocco

Cretaceous, Komen

Cenomanian, Lebanon

Campanian-Maastrichtian, Antarctica

Campanian, Germany, Westphalia

\section{Reference}

34

6, 10, 34, 37

34

34

32

9

7,37

16

24

31

25

32,34

Cenomanian, Lebanon

33,34

Cenomanian, Lebanon

14

Cenomanian, Lebanon 18

Senonian, Lebanon $\quad 14$

Senonian, Lebanon $\quad 14$

Senonian, Lebanon 20

Cenomanian, Lebanon $\quad 18,33,34$

Turonian, England $\quad 34$

Santonian, Kansas $\quad 37$

Cenomanian, Lebanon $\quad 14$

Senonian, Lebanon $\quad 14$

Senonian, Lebanon $\quad 20$

Turonian, Hvar $\quad 35$

Turonian, Croatia $\quad 35$

?Turonian, England 33, 46

Turonian, Brazil 13

Cenomanian, Mexico 2

Santonian, USA, Kansas $\quad 5,37$

lower Cenomanian, Hakel 41

Cenomanian-Turonian, Slovenia 41

Campanian-Maastrichtian Italy 41

aPatterson, C. 1993. An overview of the early fossil record of acanthomorphs. Bulletin of Marine Science 52:29-59.

${ }^{b}$ Friedman, M. 2009. Ecomorphological selectivity among marine teleost fishes during the end-Cretaceous extinction. Proceedings of the National Academy of Sciences 106:5218-5223.

cthis species was noted as being close to Beryx (=Hoplopteryx) lewisi and it may need to be revised

${ }^{\mathrm{d}}$ This species has also been placed in Hoplopteryx (reference 3, Arambourg 1954) and Caproberyx (reference 33, Patterson 1967)

'In an original reprint of this paper, the author had struck-out Serratocentrus and written "Probablement Alloberyx" 


\section{References referred to by number in Appendix 1}

1. Alvarado-Ortega, J., and B.A. Than-Marchese. 2012. A Cenomanian aipichthyoid fish (Teleostei, Acanthomorpha) from America, Zoqueichthys carolinae gen. et sp. nov. from El Chango quarry (Cintalapa Member, Sierra Madre Formation), Chiapas, Mexico. Revista Mexicana de Ciencias Geológicas 29:735-748.

2. Alvarado-Ortega, J., and B.A. Than-Marchese. 2013. The first record of a North American Cenomanian Trachichthyidae fish (Acanthomorpha, Acanthopterygii), Pepemkay maya, gen. et sp. nov., from El Chango quarry (Sierra Madre Formation), Chiapas, Mexico. Journal of Vertebrate Paleontology 33:48-57.

3. Arambourg, C. 1954. Les poissons crétacés du Jebel

Tselfat (Maroc). Notes et Memoires du Service Géologique, Maroc 118:1-188.

4. Bannikov, A.F., and C. Sorbini. 2005. A new beryciform genus and family from the Cenomanian of Hajula (Lebanon). Fourth International Meeting on Mesozoic Fishes - Systematics, Homology, and Nomenclature, August 8th-14th, 2005, Miraflores de la Sierra, Madrid, Spain, Extended Abstracts pp. 29-32.

5. Bardack, D. 1976. Paracanthopterygian and acanthopterygian fishes from the Upper Cretaceous of Kansas. Fieldiana Geology 33:355-374.

6. Bardack, D., and S. Teller-Marshall. 1982. First Cretaceous specimens of the beryciform fish Hoplopteryx from North America and their bearing on acanthopterygian evolution. The Pearce-Sellards Series, Occasional Publication of the Texas Memorial Museum, University of Texas at Austin 34:1-14.

7. Cockerell, T.D.A. 1919. Some American Cretaceous fish scales, with notes on classification and distribution of Cretaceous fishes. United States Geological Survey Professional Paper 120-I:165-202.

8. Delbarre, D.J., M. Friedman, and D. Davesne. 2014. New insights into the anatomy and relationships of Aipichthys nuchalis from the Late Cretaceous (Cenomanian) English Chalk. The Arthur Smith Woodward 150th Anniversary Symposium, May 21st 2014, Abstracts pp. 31-32.

9. D’Erasmo, G. 1922. Catalogo dei Pesci fossili delle Tre Venezie. Memorie dell'Instituto Geologico della R. Universita di Padova 6:5-180.

10. Ekrt, B., M. Košt'ák, M. Mazuch, S. Voligt, and F. Wiese. 2008. New records of teleosts from the late Turonian (Late Cretaceous) of the Bohemian Cretaceous Basin (Czech Republic). Cretaceous Research 29:659-673.

11. Filleul, A., and D.B. Dutheil. 2001. Spinocaudichthys oumtkoutensis, a freshwater acanthomorph from the Cenomanian of Morocco. Journal of Vertebrate Paleontology 21:774-780.

12. Forey, P.L., L. Yi, C. Patterson, and C.E. Davies. 2003. Fossil fishes from the Cenomanian (Upper Cretaceous) of Namoura, Lebanon. Journal of Systematic Palaeontology 1:227-330.

13. Gallo-da-Silva, V., and F.J. de Figueiredo. 1999. Pelotius hesselae, gen. et sp. nov. (Teleostei: Holocentridae) from the Cretaceous (Turonian) of Pelotas Basin, Brazil. Journal of Vertebrate Paleontology 19:263-270.
14. Gaudant, M. 1969. Sur quelques nouveaux poissons bérycoïdes crétacés du Mont Liban. Notes et Mémoires sur le MoyenOrient, Muséum National d'Histoire Naturelle, 10:273-283.

15. Gaudant, M. 1978a. Contribution à l'étude anatomique et systématique de l'ichthyofaune cénomanienne du Portugal. Première partie: les "acanthopterygiens". Comunicaçóas dos Servicos Geologicos de Portugal 63:105-149.

16. Gaudant, M. 1978b. Contribution à une révision des poissons crétacés du Jbel Tselfat (Rides prérifaines, Maroc). Notes du Service Géologique du Maroc 39:79-124.

17. Gayet, M. 1980a. Recherches sur l'ichthyofaune cénomanienne des Monts de Judée: les “acanthoptérygiens”. Annales de Paléontologie Vertébrés 99:7-46.

18. Gayet, M. 1980b. Contribution à l'étude anatomique et systématique des poissons cénomaniens du Liban, anciennement placés dans les acanthoptérygiens. Mémoires du Muséum National d'Histoire Naturelle, nouvelle série, C, Sciences de la Terre 44:3-149.

19. Gayet, M. 1980c. Découverte dans le Crétacé de Hadjula (Liban) du plus ancien Caproidae connu. Étude anatomique et phylogénétique. Bulletin eu Museum Nationale d'Histoire Naturelle, Paris 4e série, 2, section C 3:259-269.

20. Gayet, M. 1982. Étude anatomique et systématique des acanthoptérygiens du Sénonien de Sahel-Alma (Liban). Palaeontographia Italica 72:98-136.

21. González-Rodríguez, K.A., and C. Fielitz. 2008. A new species of acanthomorph fish from the Upper Cretaceous Muhi Quarry, Hidalgo, Central Mexico; pp. 399-411 in G. Arratia, H.-P. Schultze, and M.V.H. Wilson. Mesozoic Fishes 4 - Homology and Phylogeny. Verlag Dr. Friedrich Pfeil, München, Germany.

22. González-Rodríguez, K.A., H.-P. Schultz, and G. Arratia. 2013. Miniature armored acanthomorph teleosts from the Albian/Cenomanian (Cretaceous) of Mexico; pp. 457-487 in G. Arratia, H.-P. Schultze, and M.V.H. Wilson. Mesozoic Fishes 5 - Global Diversity and Evolution. Verlag Dr. Friedrich Pfeil, München, Germany.

23. Gorjanović, D. 1891. Aigialosaurus, novi gušer iz drednih škriljeva otoka Hvara s obzirom na opisane jur lacertide Komena i Hvara. Rad Jugoslavenske Akademije Znanosti i Umjetnosti 13:96-123 (part 1 Stratigrafički i faunistički odnašaji Hvara, Komena i Hakela, a table of comparison including fish fauna).

24. Gorjanovic-Kramberger, D. 1895. De piscibus fossilibus Comeni, Mrzleci, Lesinæ et M. Libanonis et appendix de piscibus oligocaenicis ad Tüffer, Sagor et Trifail. Djela Jugoslavenske Akademije Znanosti i Umjetnosti 16:1-68.

25. Grande, L., and S. Chatterjee. 1987. New Cretaceous fish fossils from Seymour Island, Antarctic Peninsula. Palaeontology 30:829-837.

26. Murray, A.M., and S.L. Cumbaa. 2013. Early Turonian acanthomorphs from Lac des Bois, Northwest Territories, Canada. Journal of Vertebrate Paleontology 33:293-300. 
27. Murray, A.M., and M.V.H. Wilson 2014. Four new basal acanthomorph fishes from the Late Cretaceous of Morocco. Journal of Vertebrate Paleontology 34:34-48.

28. Newbrey, M.G., A.M. Murray, M.V.H. Wilson, D.B. Brinkman, and A.G. Neuman. 2013. A new species of the paracanthopterygian Xenyllion (Sphenocephaliformes) from the Mowry Formation (Cenomanian) of Utah, USA; pp. 363-384 in G. Arratia, H.-P. Schultze, and M.V.H. Wilson. Mesozoic Fishes 5 - Global Diversity and Evolution. Verlag Dr. Friedrich Pfeil, München, Germany.

29. Otero, O. 1997. Un nouveau genre d'Aipichthyoidea (Teleostei, Acanthomorpha) du Cénomanien inférieur marin de Hgula (Liban): description et relations phylogénétiques. Comptes Rendus de l'Academie des Sciences de Paris, Sciences de la Terre et des Planètes 325:453-458.

30. Otero, O., and M. Gayet. 1996. Anatomy and phylogeny of the Aipichthyoidea nov. of the Cenomanian Tethys and their place in the Acanthomorpha (Teleostei). Neues Jahrbuch fuer Geologie und Paläontologie Abhandlungen 202:313-344.

31. Otero, O., Y. Dutour, and M. Gayet. 1995. Hgulichthys, nouveau genre de Lissoberycinae (Trachichthyiformes, Trachichthyoidea) du Cénomanien inférieur marin de Hgula (Liban). Implications phylogénétiques. Geobios 28:711-717.

32. Patterson, C. 1964. A review of Mesozoic acanthopterygian fishes, with special reference to those of the English Chalk. Philosophical Transactions of the Royal Society of London. Series B, Biological Sciences 247:213-482

33. Patterson, C. 1967. New Cretaceous berycoid fishes from the Lebanon. Bulletin of the British Museum (Natural History) Geology 14:67-109.

34. Patterson, C. 1968. The caudal skeleton in Mesozoic acanthopterygian fishes. Bulletin of the British Museum (Natural History) Geology 17:49-102.

35. Radovčić, J. 1975. Some new Upper Cretaceous teleosts from Yugoslavia with special reference to localities, geology and palaeoenvironment. Palaeontologia Jugoslavica 17:7-55.

36. Steindachner, F. 1864. Beiträge zur Kenntniss der Fossile Fische Oesterreichs. Sitzungsberichte der K. Akademie der Wissenschaften, Vienna, Mathematisch-naturwissenschaftliche Klasse, 47:128-142. [not seen]
37. Stewart, J.D. 1996. Cretaceous acanthomorphs of North America; pp. 383-394 in G. Arratia and G. Viohl (eds.) Mesozoic Fishes - Systematics and Paleoecology. Verlag Dr. Friedrich Pfeil, München, Germany.

38. Taverne, L. 2003. Les poissons crétacés de Nardò. $14^{\circ}$. Lissoberyx pugliensis sp. nov. (Teleostei, Beryciformes, Trachichthyidae). Bollettino del Museo Civico di Storia Naturale di Verona 27:3-13.

39. Taverne, L. 2004. Les poissons crétacés de Nardò. $17^{\circ}$. Aspesaipichthys cavaensis gen. et sp. nov. (Teleostei, Acanthomorpha, Aipichthoidea). Bollettino del Museo Civico di Storia Naturale di Verona 28:3-15.

40. Taverne, L. 2011. Les poissons du Santonien (Crétacé supérieur) d'Apricena (Italie du Sud). $3^{\circ}$. Apricenaichthys italicus gen. et sp. nov. (Teleostei, Polymixiiformes). Bollettino del Museo Civico di Storia Naturale di Verona 35:3-18.

41. Tyler, J.C., and L. Sorbini. 1996. New superfamily and three new families of tetraodontiform fishes from the Upper Cretaceous: the earliest and most morphologically primitive plectognaths. Smithsonian Contributions to Paleobiology 82:1-59.

42. Tyler, J.C., P. Bronzi, and A. Ghiandoni. 2000. The Cretaceous fishes of Nardò. $11^{\circ}$. A new genus and species of Zeiformes, Cretazeus rinaldii, the earliest record for the order. Bollettino del Museo Civico di Storia Naturale di Verona 24:11-28.

43. von der Marck, W. 1863. Fossile Fische, Krebse und Pflanzen aus dem Plattenkalk der Jungsten Kreide in Westphalen. Palaeontographica 11:1-83.

44. von der Marck, W. 1873 [1876]. Neue Beiträge zur Kenntniss der fossilen Fische und anderer Thierreste aus der jüngsten Kreide Westfalens, sowie Aufzählung sämmtlicher seither in der westfälischen Kreide aufgefundenen Fischreste. Palaeontographica Beiträge zür Naturgeschichte der Vorwelt 22:55-74.

45. von der Marck, W. 1885. Fische der oberen Kreide Westfalens. Palaeontographica 22:233-267. [not seen]

46. Woodward, A.S. 1902. Fishes of the English Chalk. The Trustees of the British Museum, London, volume 4, $406 \mathrm{pp}$.

47. Woodward, A.S. 1942. Some new and little-known Upper Cretaceous fishes from Mount Lebanon. Annals and Magazine of Natural History, 11th series 9:537-568. 